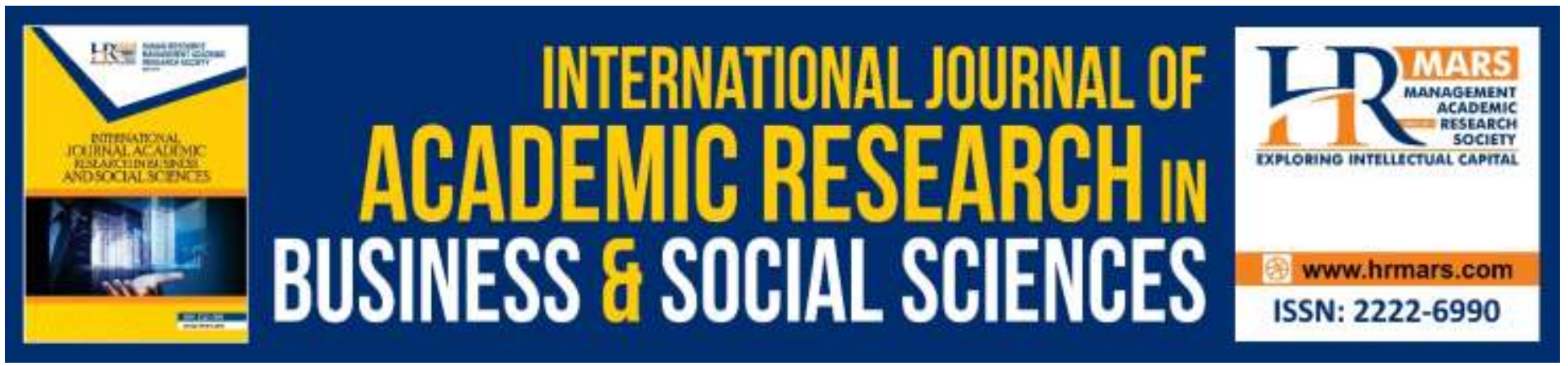

\title{
Proposed Landscape Architecture Master Program: A Feasibility Study
}

Alamah Misni

To Link this Article: http://dx.doi.org/10.6007/IJARBSS/v9-i13/6242

DOI: $10.6007 /$ IJARBSS/v9-i13/6242

Received: 20 March 2019, Revised: 19 May 2019, Accepted: 12 June 2019

Published Online: 20 August 2019

In-Text Citation: (Misni, 2019)

To Cite this Article: Misni, A. (2019). Proposed Landscape Architecture Master Program - A Feasibility Study. International Journal of Academic Research in Business and Social Sciences, 9(13), 54-66.

Copyright: (C) 2019 The Author(s)

Published by Human Resource Management Academic Research Society (www.hrmars.com)

This article is published under the Creative Commons Attribution (CC BY 4.0) license. Anyone may reproduce, distribute, translate and create derivative works of this article (for both commercial and non-commercial purposes), subject to full attribution to the original publication and authors. The full terms of this license may be seen

at: http://creativecommons.org/licences/by/4.0/legalcode

Special Issue: Revolutionizing Education: Challenges, Innovation, Collaboration, 2019, Pg. 54 - 66

http://hrmars.com/index.php/pages/detail/IJARBSS

JOURNAL HOMEPAGE

Full Terms \& Conditions of access and use can be found at http://hrmars.com/index.php/pages/detail/publication-ethics 


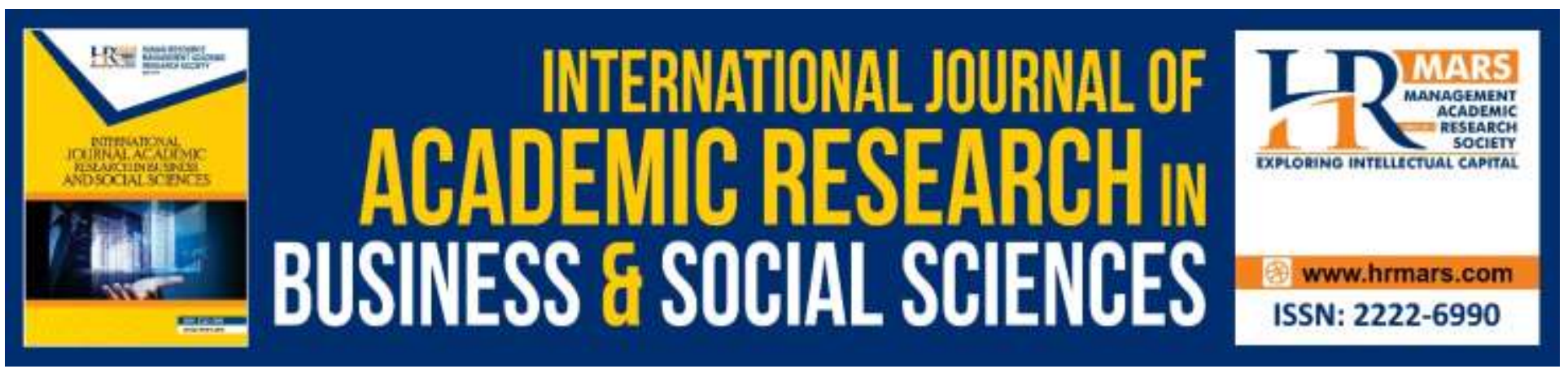

\title{
Proposed Landscape Architecture Master Program: A Feasibility Study
}

\author{
Alamah Misni \\ Faculti of Architecture, Planning and Surveying, Universiti Teknologi MARA, 42300 Puncak Alam, \\ Selangor, Malaysia
}

\begin{abstract}
As part of the government aspiration of the Universiti Teknologi MARA (UiTM) to add the enrolments' every year, all faculties are continuously expanding and increase its students. Since the Faculty of Architecture, Planning, and Surveying (FSPU) have set its aim that each department should begin their Master by coursework program, the Centre of Studies for Landscape Architecture is observing similar task and will gear up its capability with the aim to initiate the program. The market demand is examined to foresee sufficient candidates in establishing the new master program using quantitative methods in the questionnaire survey form. The target group of respondents is 150 professionals from built environment disciplines, worked at Klang Valey in government and private sectors. The data were analysed and calculated by SPSS and presented in tabular and graph. Most potential professional background candidates to be in the program are Landscape Architects, which representing $80 \%$ amongst those interested to further their study. Landscape Management is the most preferred field as their future specialization, while the prospective candidates choose UiTM Shah Alam in conducting this master program. The findings of this study may provide a basis for new employment opportunities, particularly for Bumiputera in Malaysia, and possibly throughout the world.
\end{abstract}

Keywords: Built Environment, Curriculum, Landscape Architects, Master Program, Postgraduates

\section{Introduction}

The profession of landscape architecture was made known in the country in the early 1980's with the registration of Angkatan Landskap Arkitek Malaysia (ALAM). In 1987, it was changed as Institute of Landscape Architects Malaysia (ILAM) (LAM, 2011). Throughout the years, the role of landscape architects has expanded from beautification approaches towards a comprehensive planning in regional scale. The scope of practice of the profession is more diverse, includes environmental restoration, preservation of natural resources and conservation of cultural and historical sites (Jellicoe \& Jellicoe, 1987). The landscape architecture profession is now frequently involved with wide ranges of allied professions including architecture, civil engineering, and horticulture (Baird, 2007). 
They draw on the areas of ecology, geology, sociology, hydrology, forestry, and other social, natural, and applied sciences for the nature conservation and stewardship of the land, and resulting in the enrichment or outdoor spaces for human use and enjoyment (Esparza \& McPherson, 2009; NPS, 2017). AlLA (2017) stressed that Landscape Architecture is a dynamic profession. Practitioners have come to landscape architecture from a wide range of backgrounds and possess an extraordinary range of skills. Southeast Asia is one of the world's fastest-growing markets and one of the least well known (Vinayak, Thompson \& Tonby, 2016). The potential in Southeast Asia is immense along with the rapid development in each country as well as throughout the world; the demand for landscape architects are strong. According to AFTA (2017), as professionals, architects and landscape architects from all over the world will be able to practice in Malaysia without restriction. This demand will give a positive sign for the University to start its graduate program to produce more local graduates to compete on the open market. An interesting statistical evaluation also highlights the fact that in the United States, arguably the most mature markets for landscape architects, there is approximately one landscape architect for every 10,000 persons. The ratio in Singapore is approximately 1:60,000, while the rate in Malaysia is 1: 175,000 (CME, 2005). The proportion of the landscape architect in Malaysia is very far (almost triple less) compared to developed countries such as Singapore. Many landscape architects are needed in Malaysia towards a green and sustainable developed country in 2025.

The Faculty of Architecture, Planning and Surveying at the Universiti Teknologi MARA was set up in 1967 as the School of Applied Arts. The School was separated into two art-based different schools in 1971, which was then set with a new name as the School of Art and Architecture. Over the time, the School has been upgraded and now known as the Faculty of Architecture, Planning and Surveying (FSPU). It has been significantly expanded and the curriculum offers a broad range of study in built environment including architecture; interior architecture; landscape architecture; building surveying; town and regional planning; estate management; construction management; quantity surveying; geomatic science; and parks \& amenity management. The beginning of formal education in landscape architecture in the country started by ITM (later known as UiTM) with the opening of Diploma in Landscape Design program in 1985. However, the first bachelor program in the country was initiated by Universiti Teknologi Malaysia (UTM) in 1993, follows by the bachelor program by UiTM in 1995 and beginning of 1998; the International Islamic University of Malaysia (UIAM) begins their bachelor program in landscape architecture. Currently, there are two local universities run master of landscape architecture program. The graduate study in the landscape architecture started by Universiti Putra Malaysia (UPM) with Master by-taught, 2-year programs in 1996. Followed by the Universiti Sains Malaysia (USM) started their 2-year Master program by-taught in 1998. The undergraduate level curriculum structure of landscape architecture in UiTM is established based on six bodies of knowledge, namely as constructions, design, plant sciences and design, landscape sciences, humanities, and trade and practice. The new curriculum is fabricated with the objective to generate graduates who are proficient; right professionals; scientifically and quantitatively literate; creative; and have multicultural and global understanding, perspective and vision (Thompson, 2000; Francis, 2001; Baharun, 2004; FSPU, 2005). Similarly, in the Landscape Architecture Body of Knowledge Study Report (ASLA, 2003; Williams, 2017) should contain nine domains as follows:

a. Landscape architectural history and criticism

b. Natural and cultural systems 

c. Design and planning theories and methodologies
d. Public policy and regulation
e. Design, planning, and management at various scales and application
f. Site design engineering: materials, methods, technologies and application
g. Construction documentation and administration
h. Communication, and
i. Values and ethics in practice

A survey was conducted amongst members of organizations of the American Society of Landscape Architects (ASLA), Council of Educators in Landscape Architecture (CELA), Council of Landscape Architecture Registration Boards (CLARB), and Canadian Society of Landscape Architects (CSLA). It reveals that these bodies of knowledge need to be covered 'at least adequately' in the first professional degree university programs. Respondents also indicate that in these areas, 'competency' must be initiated during or before the first professional degree and must be continued, embellished and refined in practice (ASLA, 2003). It reveals that these bodies of knowledge need to be covered 'at least adequately' in the first professional degree university programs. It also indicates that in these areas, 'competency' must be initiated during or before the first professional degree, and must be continued, embellished and refined in practice (ASLA, 2003; Williams, 2017). The result indicates that there is a possibility of providing a specialized curriculum in the proposed master program. It is as part of the preparation stage for future landscape architects to have sufficient training to be competent in the specific area of their interest as well as to cope with future globalization. To be competent, it is also important for the program to be fully recognized by the Institute of Landscape Architects Malaysia (ILAM) (Shariff, 2005). It is noted that the only local graduate program that has been fully recognized by ILAM is the Master in Landscape Architecture from UPM. On the other hand, it is also important for any institution to understand the needs and wants amongst the public in attracting students to have their further study at the University. The result of the survey will also be an important indicator for the department in guiding developing a master program. The aim of the study is to explore the market perception and need towards the possibility of commencing the program in the faculty and to prepare the latest knowledge and competencies at the graduate level curriculum of landscape architecture.

\section{Materials and Methods}

The quantitative survey is conducted by distributing a survey form (questionnaires) amongst prospective environmental built professionals who may have the interest of pursuing their Master level studies in the landscape architecture program. 150 targeted respondents were selected for staffs of private organizations and government agencies which involve directly in the similar field. The member of the faculty, Alumni is also amongst the most useful platform for obtaining potential participants. The target group of respondents is from both government and private sectors located in Klang Valley areas such as the Public Work Department, National Landscape Department, local authorities, consulting firms, landscape contractors, developers, and Forestry Department. Most respondents are selected within the Klang Valley area, given the fact that the program is to be held at the Shah Alam campus. To facilitate respondents in making their decision, the questionnaire is divided into two types of questions; close and open-ended questions. The close-ended questions are 
provided with a list of possible answers for them to choose suitably. The end list is an open-ended answering scheme if the respondents decide to give their personal suggestion. The survey form is divided into two parts, which are the respondent's background and the subject matter. The respondent's background data will include their organization, their academic background, and the possibility for them to further their study. The following questions are only for those who have the interest in continuing their study in the landscape architecture. The questions proceed in finding out respondents' preference for the program structure, program module and preferably duration of the survey. To be competent with the globalization era, the department also seeks any possibility of proposing towards a specialized program of graduate landscape architecture. This area of specializations was introduced based on the tendency of present needs as well as the strength in built environment available at the faculty. It is aimed to train built environment professionals in practicing landscape architectural professions with the stated specialized fields as follows:
a. Landscape Design
b. Landscape Management
c. Landscape Planning
d. Sustainable Landscape Construction
e. GIS (Geographical Information System)
f. Landscape Business Management
g. Environment.
h. Others

The three subsequent questions are to explore the potential of the faculty in conducting the program as compared to other local universities. This follows with the importance of ILAM recognition of the program. Finally, the last open-ended question is provided for respondents to give some general information about the survey form. The data and information will then be analysed and calculated by Statistical Package for the Social Sciences (SPSS) statistic to predict the prospect of opening the new program by the Department and presented in tabular and graph.

\section{Results and Discussion}

The results of data analysis and the findings of the study are divided into two main sections. The first section describes the main features about the background of the respondents. This section presents the background of 150 respondents who participated in the study. The demographic information solicited from the respondents was the type and location of the organizations, personal qualifications and years of working experience achieved. Another section focuses on the prospective respondents in a Master Landscape Architecture program. The top largest employer was the government bodies/agencies which employed more than half (53.3\%) of those interviewed. Others comprised of those who worked in consulting firms (20.0\%), contractors $(12.7 \%)$, developers $(2.7 \%)$, the institution of higher learning (2.7\%) and other organizations (8.7\%) such as manufacturing plants. Except for one respondent $(0.7 \%)$ from Southern Peninsular, all others (99.3\%) worked in Klang Valley. 


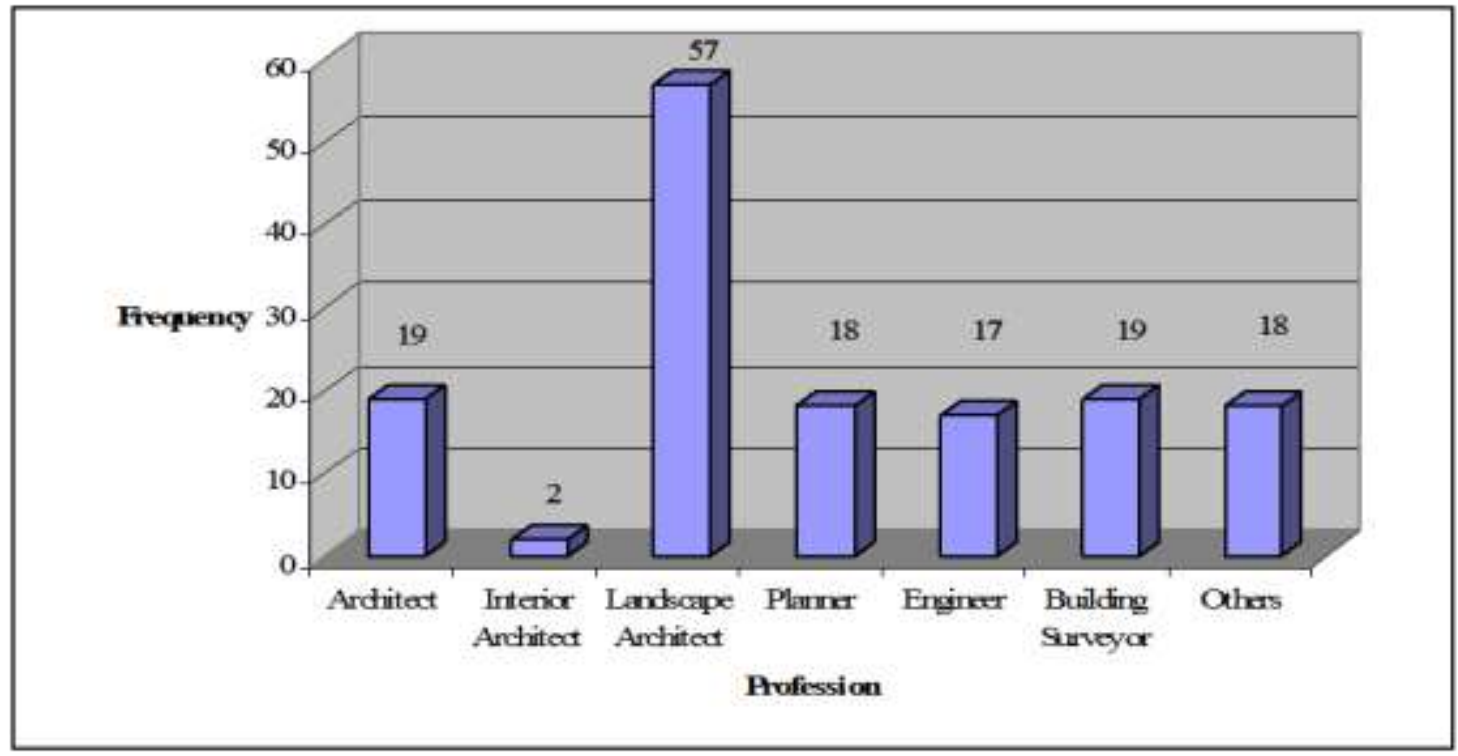

Figure 1: Professional Background

The main target respondents in the study were the built environment professions of government sectors and private companies. Figure 1 shows that Landscape Architects constituted is the largest group of professionals comprising of 57 respondents or $38 \%$ of the total respondents. Other professionals were Building Surveyors (19 respondents), Architects (19 respondents), Planners (18 respondents), others (18 respondents), Engineers (17 respondents) and Interior Architects (2 respondents). Among those lumped under 'others' were Safety Executive, Horticulturist, Ecologist, and Forestry.

Table 1: Professional Working Experience

\begin{tabular}{|c|c|c|c|c|c|c|c|}
\hline \multicolumn{2}{|c|}{ Professional/working experience } & \multicolumn{4}{|c|}{ Working experience } & \multirow[t]{2}{*}{ Total } & \multirow[t]{2}{*}{ (\%) } \\
\hline & & $<2$ yrs & $2-5$ yrs & $5-10$ yrs & $>10$ yrs & & \\
\hline \multirow{6}{*}{$\begin{array}{l}\text { Professional } \\
\text { background }\end{array}$} & Architect & 7 & 5 & 2 & 5 & 19 & 13 \\
\hline & Interior Architect & 0 & 0 & 2 & 0 & 2 & 1 \\
\hline & Landscape Architect & 18 & 16 & 11 & 12 & 57 & 38 \\
\hline & Planner & 2 & 7 & 7 & 2 & 18 & 12 \\
\hline & Engineer & 2 & 3 & 4 & 8 & 17 & 11 \\
\hline & Others & 14 & 7 & 2 & 14 & 37 & 25 \\
\hline \multicolumn{2}{|l|}{ Total } & 43 & 38 & 28 & 41 & 150 & 100 \\
\hline
\end{tabular}

Table 1 shows that the largest proportion (29\% or 43 respondents) of those interviewed had less than two years of working experience. However, about equal number also had more than ten years of working experience. The range of years of working experience as the landscape architect was wide from less than two years to more than a decade. The majority of them has experienced landscape architects, in the comfort zone of career and stable income may use this opportunity to further their study. As shown in Table 2, the majority (73\% or 109 respondents) of respondents indicated their 
interest in further studies while the remaining respondents were not interested. In fact, their interest to pursue in any graduate program was wide among various professionals. The majority of landscape architects (41\% or 45 respondents) as landscape architects interested in further their study in Master of Landscape Architecture. As expected similar further courses will bring them to upgrade their knowledge and career clearly. However, other disciplines in built environments such as planners, architects, and engineers also show their interest with 17, 14 and 10 feedbacks respectively. These small groups will further their study together with landscape architects in the different major subject; master in landscape architecture will explore new areas that hope will bring them a better future.

Table 2: Professionals by Interest to Further Studies

\begin{tabular}{llccc}
\hline \multirow{2}{*}{ Professional/Further study } & \multicolumn{2}{c}{ Interest in further studies } & Total \\
\cline { 2 - 4 } & & Interested & Not interested & \\
\hline Professional & Architect & 14 & 5 & 19 \\
background & Interior Architect & 0 & 2 & 2 \\
& Landscape Architect & 45 & 12 & 57 \\
& Planner & 17 & 1 & 18 \\
& Engineer & 10 & 7 & 17 \\
& Others & 23 & 14 & 37 \\
\hline Total & 109 & 41 & 150 \\
\hline
\end{tabular}

Table 3: Professional Background by the Main Area of Interest

\begin{tabular}{llccc}
\hline Profession/Area interest & \multicolumn{2}{c}{ Area of interest } & \multirow{2}{*}{ Total } \\
\cline { 3 - 4 } & & $\begin{array}{c}\text { Landscape } \\
\text { Architecture }\end{array}$ & Others & \\
\hline Professional & Architect & 7 & 7 & 14 \\
background & Landscape & 36 & 9 & 45 \\
& architect & & & \\
& Planner & 11 & 6 & 17 \\
& Engineer & 2 & 11 & 10 \\
& Others & 12 & 41 & 109 \\
\hline Total & & 68 & & 23 \\
\hline
\end{tabular}

Among those who intended to further their studies, the largest number (68 respondents or $62 \%$ ) chose Landscape Architecture as their area of interest. The remaining respondents preferred in other sectors. A more detailed breakdown of the types of organizations related to whose interest in Landscape Architecture. Incidentally, the largest number (33 respondents) of those interested in Landscape Architecture was working with the various government agencies. Next, the largest number (19 respondents) was employed as consultants (private firms). In fact, among the landscape architects who wanted to further their studies, they intended to do so in an area similar to their profession most probably at postgraduate level as evidence from Table 3. Among the planners, the greatest proportion (16\% or 11 respondents) was also interested to further their studies in Master in 
INTERNATIONAL JOURNAL OF ACADEMIC RESEARCH IN BUSINESS AND SOCIAL SCIENCES

Vol. 9, No. 13, Special Issue: Revolutionizing Education: Challenges, Innovation, Collaboration., 2019, E-ISSN: 2222-6990 @ 2019 HRMARS

Landscape Architecture program. On the other hand, the engineers showed the least interest in Landscape Architecture program.

Table 4: Working Experience in the Main Area of Interest

\begin{tabular}{llccc}
\hline \multirow{2}{*}{\begin{tabular}{l} 
Working Experience/Area \\
\cline { 3 - 4 } interest
\end{tabular}} & \multicolumn{2}{c}{ Area of interest } & Total \\
\cline { 3 - 4 } & & Landscape & Other & \\
\hline Years of & Less than 2 years & 20 & $\mathrm{~s}$ & \\
working & Between 2 to 5 years & 20 & 13 & 33 \\
experience & Between 5 to 10 years & 14 & 11 & 31 \\
& More than 10 years & 14 & 9 & 23 \\
\hline Total & & 68 & 41 & 22 \\
\hline
\end{tabular}

The listed results in Table 4 also reveals that irrespective of years of working experience, the majority (over $50 \%$ of the respondents) were interested in further studies in Landscape Architecture program. Those who were interested in further studies did so to improve their career development or in compliance with their existing qualification or line with the nature of their current organization as well as to a challenge even more excellent job career.

Table 5: Preferred Program Structure

\begin{tabular}{lcc}
\hline Program structure & $\begin{array}{c}\text { Number of } \\
\text { respondents }\end{array}$ & Percentage(\%) \\
\hline By coursework and research & 32 & 47 \\
(taught) & 23 & 34 \\
Research-based only & 13 & 19 \\
By coursework only (taught) & 68 & 100 \\
Total & & \\
\hline
\end{tabular}

The combination of study by coursework and research was the most popular choice among the potential candidates who accounted for $47 \%$ of the respondents. Next, a popular mode of study was research-based which recorded 23 hits or $34 \%$ of the total. The least popular choice was by coursework only which accounted for only $19 \%$ of the total (Table 5 ). When asked about the program module preferred, the largest proportion (41\%) chose part-time study during the weekdays. In other words, most of those interviewed were keen to take the evening classes. The majority of the respondents who preferred to do on a part-time basis stated that they did not have enough time to attend the regular classes. On the other hand, most of the potential students who intended to do on a full-time basis believed that they could learn more in such program module (Table 6). 
INTERNATIONAL JOURNAL OF ACADEMIC RESEARCH IN BUSINESS AND SOCIAL SCIENCES Vol. 9, No. 13, Special Issue: Revolutionizing Education: Challenges, Innovation, Collaboration., 2019, E-ISSN: 2222-6990 @ 2019 HRMARS

Table 6: Choosing Module Program

\begin{tabular}{lcccccc}
\hline Module Program & \multicolumn{2}{c}{ Reason } & Total & $\begin{array}{c}\text { Percentage } \\
\text { (\%) }\end{array}$ \\
\cline { 3 - 6 } & & $\begin{array}{c}\text { To } \\
\text { learn } \\
\text { more }\end{array}$ & $\begin{array}{c}\text { Do not have } \\
\text { time to attend } \\
\text { classes }\end{array}$ & Others & & \\
\hline Program & Full time (weekdays) & 14 & 0 & 3 & 17 & 25 \\
module & Full time (weekends) & 2 & 1 & 1 & 4 & 6 \\
& Part time (weekdays) & 4 & 21 & 3 & 28 & 41 \\
& Part time (weekends) & 0 & 18 & 1 & 19 & 28 \\
\hline Total & 20 & 40 & 8 & 68 & 100 \\
\hline
\end{tabular}

When asked for their preferred duration of the study, the answers given were unanimous, irrespective of their preferred program structure, most of the respondents preferred to complete the program within a two-year period (Figure 3). Maximum two years' full-time periods is an exact duration to finish the master program as referred to the UiTM Postgraduate Centre and Ministry of higher Education Malaysia.

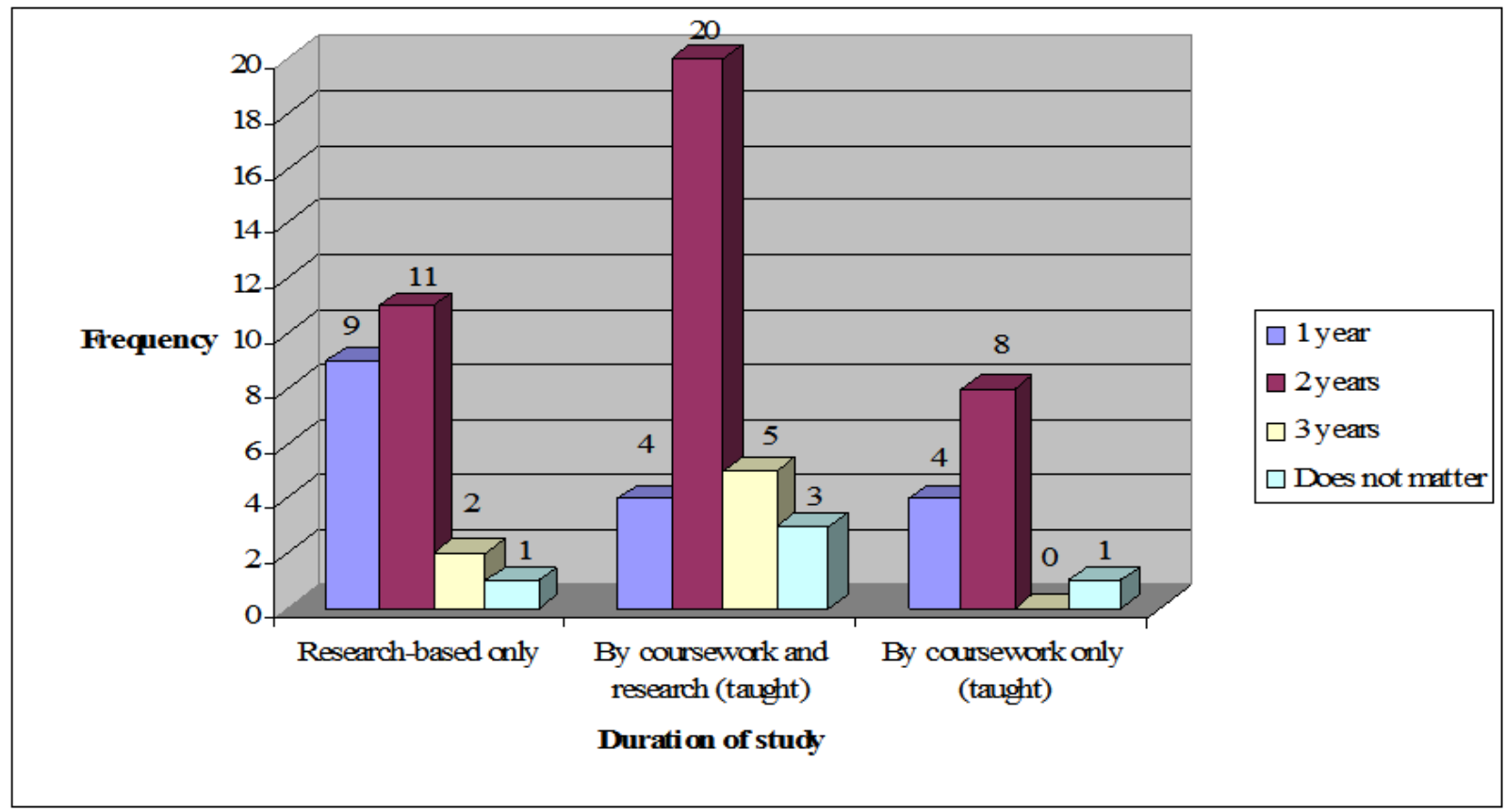

Figure 3: Preferred Program Structure and Duration of Study

The respondents were also asked for their preferred area of specialization in their Master program. For this question, they were allowed to choose more than one area of specialization provided in the questionnaire. Table 7 summarizes their responses. Among the most popular choices of specialization was Landscape Management which registered 26 hits. Next was the Landscape Planning followed by Landscape Sustainable Construction, Environment, GIS (Geographical Information System), Landscape Business Management and Landscape Design in that order preference. 
INTERNATIONAL JOURNAL OF ACADEMIC RESEARCH IN BUSINESS AND SOCIAL SCIENCES

Vol. 9, No. 13, Special Issue: Revolutionizing Education: Challenges, Innovation, Collaboration., 2019, E-ISSN: 2222-6990 @ 2019 HRMARS

Table 7: Preferred Area of Specialisation

\begin{tabular}{llc}
\hline No. & Area of specialization & Number of responses \\
\hline 1. & Landscape Management & 26 \\
2. & Landscape Planning & 21 \\
3. & Sustainable Landscape Construction & 20 \\
4. & Environment & 16 \\
5. & GIS (Geographical Information System) & 11 \\
6. & Landscape Business Management & 11 \\
7. & Landscape Design & 10 \\
8. & Others & 6 \\
\hline
\end{tabular}

The diverse background of the candidate brings benefit to the department because each candidate has experts in their area. The area of Landscape Design is aimed for those who want to specialize in landscape designing profession as well as to be a professional landscape architect, while landscape management specialization is aimed for those who involved in the area of managing the landscape. Alternatively, the area of Landscape Planning is for those who practiced on the regional scale of land planning. It is generally for those professionals who attach themselves with the Department of Town and Regional Planning. Landscape Sustainable Construction main target group is for those who work with a contractor or developer and deal with site constructions. The GIS Application is designated for those who have the interest in Geographical Information System application in huge scale of study areas, while the area of Environment is for those who interested in environmental aspects working in the environmental field that related with landscape architecture.

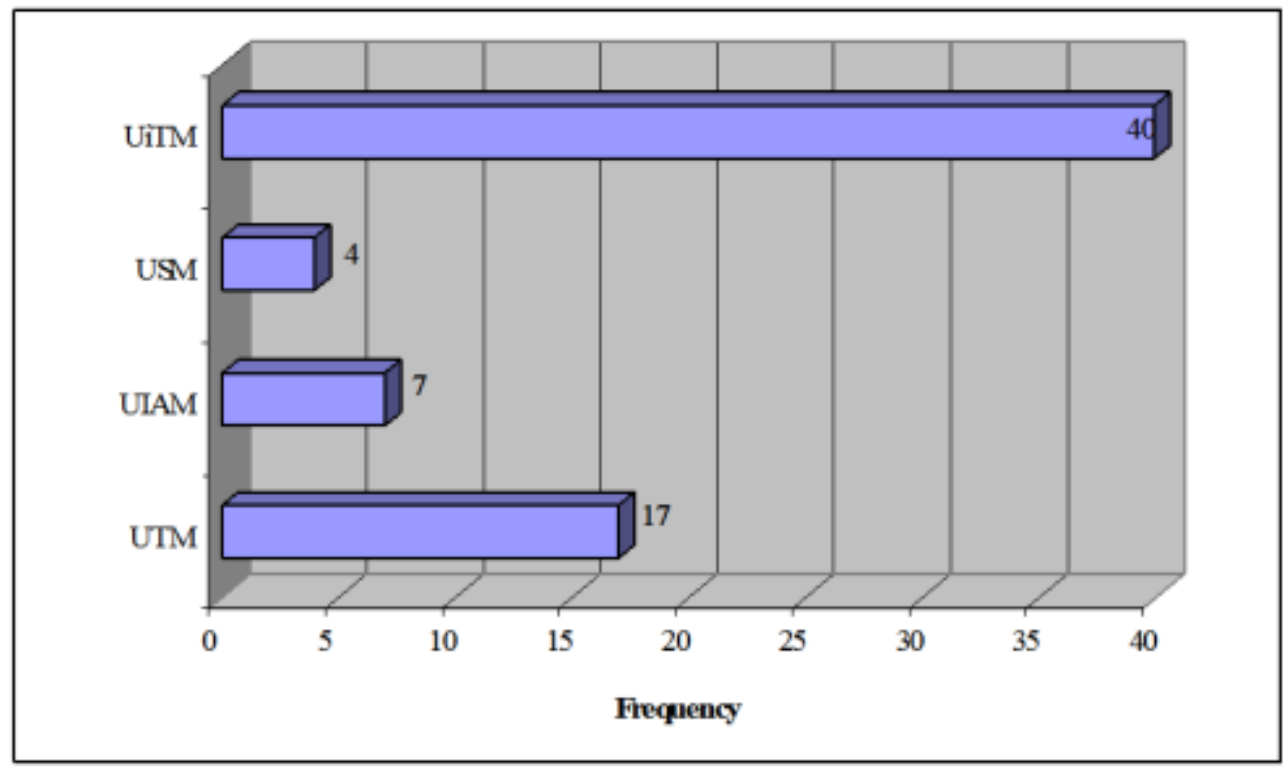

Figure 4: Preferred Institution of Learning

The vast majority, $87 \%$ (59 respondents) of the respondents picked the local universities as the first choice of location to further their studies and Shah Alam was the most important choices for a place of study. Obviously, the selection of Shah Alam was attributed to the closeness of the location to the 
place of the work of the potential students. This is evident since USM, Penang is the furthest from Klang Valley received the least votes. Therefore, the most of the respondents chose UiTM as their preferred institution. This can be seen in Figure 4 that approximately 40 respondents (60\%) chose UiTM while other respondents chose UTM, UIAM, and USM.

Table 8: Choosing UiTM as a Place of Study Master

\begin{tabular}{llcc}
\hline No. & Choosing UiTM & Number of respondents & Percentage (\%) \\
\hline 1. & Near to home & 23 & 58 \\
2. & Well known lecturers & 10 & 25 \\
3. & Less fee & 5 & 13 \\
4. & Others & 2 & 5 \\
\hline & Total & 40 & 100 \\
\hline
\end{tabular}

In addition, they were also asked for the reason for choosing the UITM as their preferred institution. As summarized in Table 8, more than half (58\%) of the respondents put 'location' as the top most important consideration because it related to time to attend the class during weekdays after working hours. Another important criterion was the perception that the UiTM's lecturers were capable and had the credible background. More importantly, the vast majority (98\%) agreed that ILAM should fully recognize any Landscape Architecture Master program. They also suggested that like other universities, UiTM should commence the program immediately as has demanded from the current built environment industries especially in the local context of Malaysia. They added that to encourage more people to pursue postgraduate studies, the universities should also consider allowing prospective students from a diverse background, but with sufficient experience in built environment and landscape architecture field to be admitted into the program.

From the analysis of the results, there is sufficient potential for the department to start an advance program in Landscape Architecture. Further analyses indicate that consultant companies are the most likely organization to acquire candidates, which $76 \%$ respondents from these private sectors show their interest to prefer further their study choose this master program. Government agencies are the next most prospective organization with $58 \%$ amongst their staff interested to further their study. Most potential professional background candidates to be in the program are Landscape Architects, which representing $80 \%$ amongst those interested to further their study. As expected landscape architects are the first target candidate group to join this master program because it's closely related to their bachelor degree. Planners are the next interest professional groups with $65 \%$ of those interested to further at master level. The prospect from Architects came to the third with $50 \%$, while $20 \%$ Engineers who interested to further their study would take this program to be their primary choice. The diversity of educational backgrounds in built environment will enliven this future master program in FSPU. Postgraduate students with a different expertise and experience backgrounds can follow this master program more effectively and may provide strength in the field of landscape architecture in the future.

Regarding the area of specialization, Landscape Management is the most preferred area representing $21 \%$ amongst those who choose the Landscape Architecture program. Landscape Management has 
the highest prospect to lead the Master program. The landscape management specialization is to fulfil the current demand on landscape management and maintenance, especially in local government and private sectors to manage the existing landscape in urban areas. The Landscape Planning and Landscape Sustainable Construction shows as the following popular area of specializations with $17 \%$ each out of all prospective candidates. They chose both fields is reflected from the global and local demand to plan our region with more green and apply low impact development to the city environment. It is also quite clear of the potential for this university to obtain a sufficient number of candidates in conducting this program since $60 \%$ prospective candidates choose UiTM, Shah Alam as their preferred place of study. The strategic location of UiTM in Klang Valley is the main motive, easy to access in short distance from their home and workplace, as well as enable them to attend a full-time schedule during weekdays after working hours. Travel cost and time will be at a minimum spent. The other factor that influence respondent to choose UiTM is because of their distinguished lecturers in Shah Alam campus. The UiTM reputation is well known among respondents in Klang Valley that encourage them to join this master program. In addition, multi-discipline courses of the built environment in FSPU also will help to hire any expertise needed to run this program smoothly in the future.

Most respondents would prefer a combination of course work and research module as their curriculum category to study this master program. Course works will teach them the specific subjects and theories, while the research module category will bring them into the new research field. The research mode is the most important and a core course in higher postgraduate education level and all students must be performed well in the real world to do a research. The typical ratio of course works and research in FSPU is between 70:30 and 60:40. The Department's is also highly recommended to conduct a 2-year program as preferred by most respondents as well as part of the requirement by ILAM for their recognition.

\section{Conclusion}

This study can conclude that the feasibility of market demand to foresee sufficient candidates in establishing the new master program in FSPU, UiTM, Shah Alam, Selangor gave encouraging results. The main target respondents in the study were the built environment professions of government sectors and private companies. Landscape Architects constituted the largest group of professionals comprising about $38 \%$ of the total respondents. Most of them represented $80 \%$ are interested in further their study in landscape architecture field and specialize in landscape management. They would prefer a combination of course work and research modules. Lectures are preferred to be held in Klang Valley area to enable them to attend during weekdays in a two year period of study. To be competent, it is also important for the program to be fully recognized by ILAM. The outcome of this study could help to envisage the feasibility of the department to introduce the Master in Landscape Architecture program at UiTM campus, Shah Alam. This study may also provide a foundation for the development of a Master in Landscape Architecture curriculum for UiTM as well as provide a basis for new employment opportunities and competitiveness particularly for professionals Bumiputera in Malaysia. 
INTERNATIONAL JOURNAL OF ACADEMIC RESEARCH IN BUSINESS AND SOCIAL SCIENCES

Vol. 9, No. 13, Special Issue: Revolutionizing Education: Challenges, Innovation, Collaboration., 2019, E-ISSN: 2222-6990 @ 2019 HRMARS

\section{Acknowledgments}

This research was partly supported by FSPU Internal Grant, Universiti Teknologi MARA (100-FSPU (PT $36 / 5 / 7 / 9)$.

\section{References}

AFTA (2017). The ASEAN Free Trade Area. Retrieved on 10 January 2017 at http://asean.org/aseaneconomic-community/asean-free-trade-area-afta-council.

AlLA. (2004). Practice Note 2 - Scope of Services: A Summary of Services Provided by Landscape Architects in Australia. The Australian Institute of Landscape Architects.

ASLA. (2003). A Survey for Landscape Architecture Body of Knowledge: Conducted on behalf of the American Society of Landscape Architects (ASLA), Canadian Society of Landscape Architects (CSLA), Council of Educators in Landscape Architecture (CELA), Council of Landscape Architecture Registration Boards (CLARB) and Landscape Architectural Accreditation Board (LAAB). USA.

Baharun, F. (2004). Identifying Needs and Wants of University Students in Malaysia. Malaysian Management Review. Malaysian Institute of Management.

Baird, C. T. \& Szczygiel, B. (2007). Sociology of Professions: The Evolution of Landscape Architecture in the United States. Landscape Review. 12(1), pp 3-25.

CME. (2005). Centre for Management Excellence, Singapore. Retrieved on 10 January 2017 at www.cme.com.sg.

Esparza A. X. \& McPherson, G. (2009). The planner's guide to natural resource conservation. Springer.

Francis, M. (2001). A Case Study Method for Landscape Architecture. Landscape Journal. Vol. 20 (1), pp. 15-29.

FSPU. (2005). Lapuran Penyemakan Semula Program Akademik Diploma in Landscape Architecture dan Bachelor of Landscape Architecture (Hons), FSPU, UiTM.

Jellicoe, G., and Jellicoe, S. (1987). The Landscape of Man: Shaping the Environment from Prehistory to the Present Day. Thames \& Hudson Ltd. The United Kingdom.

LAM. (2011). Landscape Architecture Malaysia Yearbook: 30 years of Landscape Architecture in Malaysia. Institute of Landscape Architect Malaysia (ILAM). Kuala Lumpur.

NPS. (2001). Rethinking the National Parks for the 21st Century. A Report of the National Park System Advisory Board, Retrieved on 10 January 2017 at https://www.nps.gov/policy/report.htm.

Shariff, M. K. M. (2005). Personal Communication - President of ILAM on 16 May 2005.

Thompson, I. H. (2000). Ecology, Community and Delight: Sources of Values in Landscape Architecture. Taylor \& Francis Group. New York.

Vinayak H. V., Thompson, F. \& Tonby, O. (2017). Understanding ASEAN: Seven things you need to know. Retrieved on 10 January 2017 at http://www.mckinsey.com/industries/publicsector/our-insights/understanding-asean-seven-things-you-need-to-know.

Williams, S. K. (2017). Landscape Architecture Body of Knowledge: What, Why and Why Now? Landscape Architecture Body of Knowledge Study. Retrieved on 10 January 2017 at https://www.asla.org/uploadedFiles/CMS/Education/Accreditation/LABOK_3_pages.pdf. 